\title{
Churn management in the telecom industry of Pakistan: A comparative study of Ufone and Telenor
}

Received (in revised form): 11th January, 2007

\begin{abstract}
Sadia Jahanzeb
teaches at Fatima Jinnah Women University, Rawalpindi. Her practical experience in the field includes a five years stint at the State Bank of Pakistan, as an Officer-Grade II. She has an MBA degree from the Institute of Business Administration (IBA), Karachi and a diploma in banking from the Institute of Bankers (IBP) in Pakistan. Her areas of interest are banking, finance and management.
\end{abstract}

\section{Sidrah Jabeen}

is a student of MBA at Fatima Jinnah Women University, Rawalpindi.

Keywords churn, market segmentation, teledensity, churn rate, customer attrition, cellular service, telecom sector, Pakistan

Abstract Churn management is a perennial issue in the telecom industry of Pakistan. The two telecommunication service providers selected for this study are Telenor and Ufone. The aim of the research is to provide an insight into the rapidly emerging issue of churn in the telecom sector of Pakistan, describe the relevant aspects of churn management strategies and gauge their effectiveness in customer retention. Purposive sampling has been adopted such that 100 subscribers, with 50, each of Ufone and Telenor, constitute the sample. The sample profile comprises of 100 male post-paid subscribers, of age range 30-45 years, employed in the middle management level of the corporate sector and users of either Telenor or Ufone. The survey method has been adopted, and a comparison has been drawn between the churn rates of the two service providers through the application of $T$-test. Analysis reveals that subscribers' dissatisfaction with any dimension of price, voice quality and network coverage are the main reasons for customer churn at both Ufone and Telenor. Ufone has, however, adopted comparatively better churn management strategies than Telenor to retain its customers.

Journal of Database Marketing \& Customer Strategy Management (2007) 14, 120-129.

doi:10.1057/palgrave.dbm.3250043

Sadia Jahanzeb Fatima Jinnah Women University, The Mall, Old Presidency, Rawalpindi, Pakistan Tel: 051-5950779 e-mail: idea_73_50@hotmail. com

\section{INTRODUCTION}

In the new millennium, the Pakistan telecom landscape has emerged as one of the most dynamic business sectors in the country where cell phones have become a household utility, with cellular teledensity being recorded as 19.75 per cent (March
2006)..$^{1}$ The future looks promising as a sizeable percentage of the population has enough disposable income to cater to the mobile communication industry, thus uncovering a latent potential in the market. This present scenario is a battlefront for a large number of private telecommunication 
companies where the government's decision to deregulate the telecom sector has paved the way for a number of entrants to provide cellular service. Cellular subscriptions have shot up from 5 million in the year 20032004 to 15.5 million in the year 2004$2005,{ }^{2}$ and new investment in telecom sector is being projected at US $\$ 1,159$ million in the year 2007-2008, ${ }^{2}$ making Pakistan one of the fastest-growing cellular markets. With the foray of the public sector Pakistan Telecommunication Mobile Limited (PTML) and different private multinationals into the segment, the competition has intensified with each telecom operator fighting a battle for sustainability. Rapid growth and cut-throat competition in the telecommunications sector is having a profound effect on how industry providers must now manage their strategies to attract and, most importantly, satisfy and retain their valuable customers. In the infancy state, the newly competitive market focused only upon acquiring new customers. It overlooked the retention of existing customers that at times led the subscriber base to churn, but was more or less sustainable enough to be ignored. Some of the factors contributing to increased churn are the decline in the price of handset, complimentary packages of handsets and services, which have lowered the entry barriers for clients on the positive side, but have made changing operators less of a deterrent on the negative side. Controlling internal churn while at the same time encouraging competitor's clients to churn is a challenge, especially for Greenfield operators.

This situation is now being altered due to the maturity of the telecom markets and the resulting cut-throat competition, which has caused the churn rate to be examined with a focused and systematic approach. Effective churn management allows an operator to stay ahead of competitors, increase profitability and improve investor confidence. Key strategies include incentives and tariff bundles that target the most profitable customers, loyalty schemes that are appropriate to the value of the business saved, acquisition strategies that attract the right type of customer, reduction of fraud and bad debt, proactive customer service and a commitment to quality in all aspects of the business.

\section{LITERATURE REVIEW}

Customer churn is a basic unit of the telecommunication industry, which is used to describe customer loss, more precisely defined as the gross rate of customer attrition during a given period. It assesses a service provider's customer retention efforts and provides an insight into the growth or decline of the subscriber base as well as the average length of participation in the service. ${ }^{3}$ In the telecommunication industry, customers are able to choose among multiple service providers, thus actively exercising their right to switch from one operator to another. There is a significant relationship between customer loyalty, customer satisfaction, trust and switching costs in the mobile phone market. ${ }^{4}$ In this fiercely competitive arena, subscribers demand tailored products and better services at lower prices, while service providers focus on customer acquisition as their prime business goal. Customer retention has become the key business issue for telecom companies towards the end of the 1990s. ${ }^{5}$

Yankee Group ${ }^{6}$ indicated that mobile operators estimate the cost of acquiring a new client at seven times more than the annual cost of retaining an existing subscriber on an average basis. The emergence of the digital economy has intensified the problem of churn management. Lejeune ${ }^{7}$ states that a company's initiatives to handle churn and profitability issues have been directed to more customer-oriented strategies. A customer relationship management (CRM) framework based on the integration of the electronic channel would incorporate the 
electronic dimension and be enhanced by the development of adequate tools for the collection, treatment and analysis of data which play a central role in churn management. Churn amplitude is negatively correlated with the efficiency of datamining tools, and the relationship between churn and CRM tools is linear. An analytical framework based upon sensitivity analysis could anticipate the possible impact induced by the ongoing data-mining enhancements on churn management and the decision-making process. Heejin et al. ${ }^{8}$ has developed a research model to identify multi-dimensions of mobile service quality and perceived value, and investigated their influences on satisfaction and loyalty. It has been figured out that two dimensions of perceived value (ie economic value, emotional value) had significant influence on customer satisfaction and loyalty intention.

A report on Best Practice Churn Management Strategies for pre- and postpaid customers (2002) identified the strategies that best practice operators use to combat churn for both pre- and post-paid customers. It provided an assessment of the impact versus cost/complexity of the full range of churn management strategies employed by the operators and benchmarks achieved. It showed that operators could achieve quick wins in the battle against churn by obtaining comprehensive customer information and applying this information to churn prediction. It also identified various ways to manage churn in the future as the market becomes saturated and customers tend to become extremely selective. ${ }^{9}$ Operators have to invest in CRM and database management in order to understand clients' needs and anticipate churn before it happens, putting in place actions to generate fidelity. ${ }^{10,11}$

Caruana $^{12}$ investigates the dimensions of switching costs, which influence customer loyalty by working out a correlation analysis among the corporate customers of a mobile phone operator. A better understanding of customer satisfaction, churn and win-back initiatives can reverse customer attrition, ${ }^{13}$ thus proving the adage, prevention is better than cure. Ignorance of customer risk, behaviour and profitability results in ineffective utilisation of CRM efforts. $^{14}$

\section{CLASSIFICATION OF CHURN}

There is little consistency in the measurement of churn; hence, it is very difficult to make a comparison between the churn rates of two different telecom companies. Moreover, because churn rates can make a real difference to a service provider's share price and reputation, these rates are occasionally 'massaged' to make them appear more positive. Churn levels also vary widely according to geographical markets and types of services offered, ${ }^{10}$ and may be broadly categorised as being of external or internal nature. ${ }^{15}$ External churn is defined as the switching of customers from one service-providing company to another and consists of two main sub-types, involuntary and voluntary. Involuntary churn refers to customers who are disconnected by the telecom operator. It is initiated by the telecom company and is due to unavoidable circumstances such as death of the subscriber or disconnection due to fraud, bad debt or under-utilisation. Voluntary churn in the telecommunication industry deals with measurement of customer disconnects for personal reasons like switching to a competitor, cancelling service, transferring from one place to another, etc. ${ }^{16}$ The subscriber initiates it and is either deliberate or incidental. The deliberate reasons might include pricing, poor customer service or network problems while incidental churn might arise due to financial contingencies, location or major life changes. Internal churn is defined as the switching of customers from one service to another within the same service provider company, for example, switching from 
post- to pre-paid service within the same cellular service.

Churn can also be classified as customer initiated or competitor initiated. In customer-initiated churn, the customer disconnects service, closes an account or ceases to use a given service while the company is unaware of the reasons. The major factors responsible for customerinitiated churn could be unacceptable call quality, more favourable competitor's pricing plan, unfulfilled customer expectation, billing problem, change of location, change in business, etc. In competitor-initiated churn, a competitor 'steals' the customer from an existing service provider. The reasons might be new technology, better service quality, pricing strategies or network coverage offered by the competitor.

Research dictates that customer-initiated churn is far more common and complicated, so companies need tracking indicators to predict such actions. ${ }^{10}$ The resultant information might be used as a valuable input to develop customer retention programmes.

There is no single way of reducing churn across all customer segments, as each target market will respond to an individual kind of approach based upon its need and situation. Attrition in subscribers' base might be rectified through convenient payment options or adoption of customised approach through loyalty and affinity schemes. A predictive churn model might be designed to target likely churners by keeping a record of customer profile that can then be focused on through exclusive service packages ${ }^{17}$. It also helps a service provider to retain the subscribers' base by ensuring guaranteed response time to complaints/ enquiries, brand reputation, extensive distribution network for pre- and post-paid subscriptions, promotional tie-ups with retailers, wide range of value-added services (VAS), roaming alliances, multi-year post-paid contracts and improved customer service such as good cellular coverage, radio reception along with low dropped calls, etc.

Research dictates that a logical approach to churn management might include the following steps:

- Capture of customer information

- Segmentation of the total market

- Identification of characteristics of various segments

- Location of the most flickering/floating segments

- Identification of specific reasons for churn

- Management of churn

\section{INTRODUCTION OF OPERATORS}

Two telecom service providers, namely Ufone and Telenor, have been selected to carry out a research on churn management strategies of these two operators in Pakistan. The selection of the target market involved a careful look into the lifestyle of the users of these particular mobile companies.

Another aspect that has been given due consideration in the choice of the particular companies is the fact that Ufone has reached the maturity stage in the product life cycle graph as it has been in the market for five years, whereas Telenor is a new entrant in the growth stage, with an experience of one and a half years.

Ufone was initiated on 29th January, 2001 under the umbrella of PTML to operate cellular Global System for Mobile communication (GSM) 900 services. It is a 100 per cent-owned subsidiary of Pakistan Telecommunication Company Limited (PTCL). Ufone has covered over one hundred and thirty-six key cities during the year 2004-2005 and prominent highways across Pakistan, ${ }^{2}$ providing the customers the best quality service and value for money. With an investment plan of US\$103.5 million for the year 2005-2006, a market share of 21.1 per cent for the year 2004-2005 $5^{2}$ and an aggressive commercial plan, the customer base has more than 
tripled from the fiscal year 2003-2004, taking off from 0.80 million to 2.98 million subscribers in the fiscal year 2004-2005. ${ }^{2}$ The latest figures compiled by the Pakistan Telecommunication Authority (PTA) suggest that Ufone has 7.5 million users as of 2006. Ufone pre-pay provides the facilities of voice mail, short messaging service (SMS), general packet radio service (GPRS), multi-media messaging service (MMS), international SMS and downloads to its users. Currently, the service provider offers pre-pay scratch cards in denominations of Rs. 100/-, Rs. 250/-, Rs. 500/- and Rs. 1,000/- only. The VAS available for its post-paid users include all the features of pre-paid services with the exception of call management, which is a facility for post-paid subscribers only. It claims to be the first GSM Operator in Pakistan with second-and-a-half generation of mobile communications (2.5 G) GPRS, and offers the features of high-speed data services, wireless application protocol (WAP) data services, MMS, first class customised data and voice solutions for clients, Real virtual private network (VPN) System for corporate clientele.

Telenor is a Norwegian operator, which acquired the licence for providing GSM services in Pakistan in April 2004 and launched its services commercially in Islamabad, Rawalpindi and Karachi on 15th March, 2005. On 23rd March, 2005, Telenor initiated its services in Lahore, Faisalabad and Hyderabad. The company has extensive experience in cellular operations worldwide. It now covers over one hundred and seventy-five key cities and prominent highways ${ }^{18}$ across Pakistan. Telenor has its corporate headquarters in Islamabad, with regional offices in Karachi and Lahore. The company's primary objective is to offer topquality mobile services and to promote healthy competition in the telecommunication mobile market. It has covered several milestones since its inception, and grown in a number of directions as depicted by the interconnect agreements signed during December 2004, allowing its subscribers to exchange voice and data with other active mobile networks including Paktel, Ufone and Warid. Telenor is currently providing the facilities of GPRS, MMS, SMS, International SMS, WAP and International Direct Dialling to its customers in Pakistan. Easy load and D'juice are its special packages for users offering customer services through its Call Centres and Sales \& Service Centres. The figures compiled by PTA suggest that Telenor has a market share of 6.7 per cent in the fiscal year 2004-2005. The latest figure derived from the same source gives a subscriber base of 3.5 million in the year 2006 .

\section{METHOD}

Mathematically, Churn rate can be calculated as

$$
\text { Monthly Churn }=(C 0+A 1-C 1) / C 0
$$

where $C 0$, is the number of customers at the start of the month, $C 1$, the number of customers at the end of the month, $A 1$, the gross new customers during the month. A study was designed to investigate

(a) The rapidly emerging issue of churn in the telecom industry of Pakistan and the churn management strategies adopted by telecom service providers.

(b) The retention of users through effective churn management strategies.

For this study, the following hypotheses were formulated:

(i) Ufone than Telenor will score higher on level of customer satisfaction.

(ii) Ufone than Telenor will score lower on level of churn.

The study seeks to draw a comparison between the churn management strategies adopted by two distinct service providers, each of which is placed at different stages of the product life cycle. The concept was to 
look into the strategies employed by each company through focus on their respective target market and ascertain retention measures. It is figured out that organisations focus upon individual segments through the utilisation of psychographics, which stresses upon the adoption of a particular lifestyle in order to be identified with a group. This group affiliation, in turn, forms the basis for conformation to certain values or norms.

\section{SAMPLE}

A sample comprising 100 male post-paid subscribers, 50 each in number, from Ufone and Telenor, has been selected from Islamabad. The representation of males only in the sample is based upon the convenience factor, as data was readily accessible from this target market segment. Their age profile ranges from 30 to 45 years, and includes corporate sector employees placed in the middle management cadre and enjoying a disposable income range of Pak Rs. 40,00060,000 per month. The following factors were considered while selecting subjects.

\section{A mobile service user}

(a) was using the service for at least six months;

(b) was a subscriber of either Ufone or Telenor;

(c) was working in the corporate sector;

(d) was either a pre- or a post-paid service user

\section{RESULTS}

This study applies the purposive sampling technique to focus on a particular target market, based upon the high usage rate among the specific customer segment. The selected customer group has been pointed out in the interview conducted with the management of both the organisations. The survey method has been used to gauge the churn inclination of the targeted psychographic segment. $T$-test has been applied on the data collected through questionnaires, and on that basis conclusions have been drawn and recommendations put forward.

Respondents reveal that 64 per cent of Ufone's customers and 84 per cent of Telenor's customers were utilising the services of some other cellular services before switching over to their current service. The higher figure for Telenor certainly points towards the effective target and acquisition strategies of the operator, who is able to headhunt early on a sizeable number of customers using other services (Figure 1).

Survey results establish that the major reason for customers switching over from the previous service to the current one is the poor voice quality followed by network problems, as depicted by the choice of both Ufone and Telenor customers. As far as the satisfaction level of customers is concerned, more than half of Ufone customers are satisfied with its prices and cellular coverage, but dissatisfied with the billing system. A majority of the customers of Telenor are satisfied with its cellular coverage and billing, but dissatisfied with the voice quality. The response of help-line personnel, in general, is good in both the cases. The figures are better, however, for Ufone in the case of successful resolution of customers' problems. This pinpoints the effective strategies adopted by the Ufone management for customer satisfaction and retention (Table 1).

It appears that the price sensitivity of Ufone customers is more than that of Telenor subscribers. It is also figured out that most of the customers never inform

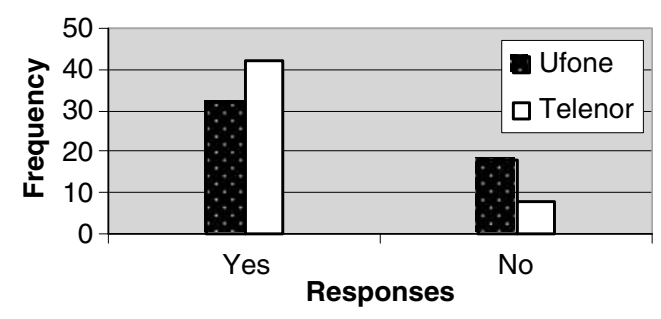

Figure 1: Customer switch-over from previous to current service 
Table 1: Reasons for churn

\begin{tabular}{llllll}
\hline Reasons & Ufone & & & Telenor \\
\cline { 2 - 3 } \cline { 5 - 5 } & Frequency & Per cent & & Frequency & Per cent \\
\hline Poor voice quality & 37 & 74 & 26 & 52 \\
Limited cellular & 0 & 0 & 2 & 4 \\
coverage & 26 & 52 & 29 & 58 \\
Network problems & 26 & 30 & 10 & 20 \\
High prices & 15 & 4 & 1 & 2 \\
Billing issues & 2 & & & \\
\hline
\end{tabular}

their service provider if they wish to switch over to some other cellular service. Some of the Ufone subscribers, however, on account of their positive earlier experiences, indirectly informed their service provider about such decisions. Thus, the rate of contacting service providers about the decision to switch over is higher in case of Ufone as compared with Telenor. Regarding the offer of exclusive packages by the service provider, it is indicated that more than half of the Ufone customers have been offered different kinds of exclusive packages by their service provider, while none of the Telenor customers have been offered such privileges. The survey also reveals that once the subscribers have decided upon a service operator, most of them are not interested in shopping around for alternative cellular service providers. The reason behind it is their desire to keep their current cell phone number that is a means of contact (Table 2).

There exists a general perception that quitting one service and switching over to another is difficult and time consuming. The introduction of mobile number portability (MNP) at the end of the year 2006 shall bring about a revolutionary change in this perception. A vast majority of Ufone customers strongly believe that their service provider has adopted effective strategies for customer retention. On the other hand, the opinion of most of the Telenor customers is that their service provider is ineffective in terms of retention strategies, which can ultimately result in attrition of customer base, in the long run (Tables 3 and 4).
The above-mentioned $T$-test shows that the mean for Ufone (2.7617) is greater than that of Telenor (2.2148) and the value for sig. (two-tailed) is zero. The application of $T$-test confirms that in comparison with Telenor, Ufone scores higher on level of customer satisfaction and, alternatively, ranks lower on the level of churn.

\section{DISCUSSION}

The data reveal that churn management plays a major role in customer satisfaction, loyalty and retention in any organisation. Ufone customers are contacted by the service-providing company itself if they do not use their cellular service for a certain time period. Churn management is a wellorganised, round-the-clock activity, performed by its retention centre, which is located in its Islamabad (North Zone) office and deals with customer churn all over Pakistan. The organisation plans to open another upcoming retention centre in Karachi (South Zone) by the year 2007. Currently, Ufone is applying two computer software, Cares and Single View, to track customer history. Cares is a universal software that is used to give a bird's-eye view of both pre- and post-paid data. Single View software, on the other hand, specifically deals with post-paid customers in detail. It helps to maintain an elaborate customer track record that tends to prevent future customer churn, identifies high value customers and offers different incentives to individual clients. The operator is currently dealing with customer churn for post-paid subscribers only; however, the company 
Table 2: Consistent cell phone number

\begin{tabular}{llcll}
\hline Responses & Ufone & & Telenor & Per cent \\
\cline { 2 - 3 } \cline { 5 - 5 } & Frequency & Per cent & Frequency & 42 \\
\hline Very true & 29 & 58 & 21 & 34 \\
True & 11 & 22 & 17 & 10 \\
Partially true & 5 & 10 & 5 & 14 \\
Not true & 5 & 10 & 50 & 100 \\
Total & 50 & 100 & 7 & \\
\hline
\end{tabular}

Table 3: Group statistics

\begin{tabular}{llllll}
\hline & VAR0001 & N & Mean & Std. deviation & Std. error mean \\
\hline VAR00002 & Ufone & 50 & 2.7617 & 0.1988 & $2.812 \mathrm{E}-02$ \\
& Telenor & 50 & 2.2148 & 0.2671 & $3.777 \mathrm{E}-02$ \\
\hline
\end{tabular}

Table 4: Independent samples test

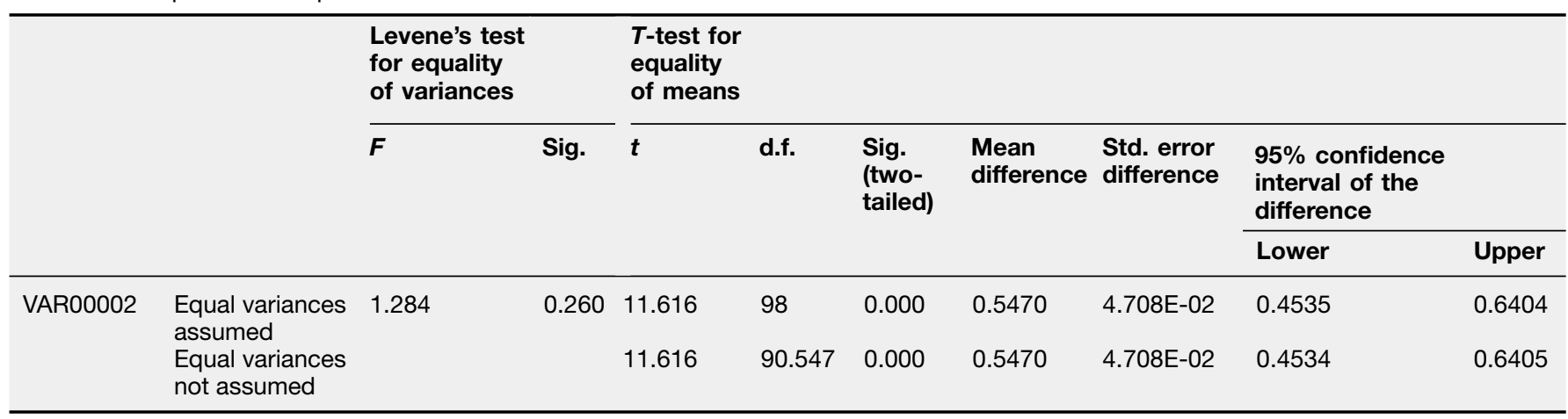

offers different packages to satisfy its prepaid users as well.

Retention centre agents keep a constant watch on Ufone post-paid customers' data all over Pakistan through Single View Software. When outgoing calls of any subscriber drop down from 70 to 92 per cent of the original number, message alerts are sent to the customer. If the situation persists for 15 days, with outgoing calls being dropped to 92 per cent, the number is marked with a tag of O-Exceed, and outgoing calls facility is blocked. If another fortnight passes with this status quo, and the customer does not contact the service provider to open the outgoing call facility, the number is marked with a tag of D-
Exceed. It is a warning that if the situation persists for 15 more days, incoming calls facility will also be blocked. After 15 days of this warning, the number is marked with a tag of TD and is temporarily disconnected. The number is permanently disconnected after exceeding 15 days of temporary disconnection (TD). After a fortnight of permanent disconnection, it reaches a quarantine stage, after which the number is allotted to some other customer, and the original subscriber cannot get reconnection of the same number even if he/she wishes to. This is an effort to retain the genuine customers and give them an edge over the non-serious subscribers. The retention department at Ufone also offers the facility 
of B-Vol (voluntary blockage) to its postpaid customers. A particular number can be blocked on customer's own request for up to 6 months due to relocation or changes in the temporary sense.

Ufone retention department offers special/exclusive packages to customers, both in individual capacity and on segmentation basis. Reward points are given to post-paid subscribers under Ufone loyalty programme that offers free of cost subscriber identity modules (SIMs), conversion from post- to pre-paid connection, line-rent waivers, talkies package, zero line rent (ZLR) package and one-month line-rent waiver, to acknowledge highly valued customers. In addition, agents deal with all types of customer queries on Ufone's retention helpline. Ideally, the hit ratio of an agent is 70 per cent per month, which implies that an agent should contact 70 per cent of the customers who are likely to churn. The restoration ratio, on the other hand, should be 60 per cent per month, that is, an agent should retain 60 per cent of the customers who have a high probability of quitting the service provider.

The situation is entirely different at Telenor, which has no churn management department, as it has not included customer retention in its contingency planning. The organisation is currently focusing on customer acquisition and infrastructure development due to which it is not utilising any software to track its customers' data or history. Telenor outsources independent surveys from time to time, to assess the service level and customers' perception. It believes that CRM, good pricing strategies and quality service ensures customer satisfaction. It remains to be acknowledged that the only mechanism to stop dissatisfied customers from leaving Telenor service is the helpline, which tries to resolve customer queries through its round-the-clock service. The rate of utilising some other cellular services before switching over to the current service is greater in case of Telenor, which again points towards the effective target and acquisition strategies of the operator. Most of Telenor's customers think that their service provider has not adopted effective strategies to retain its customers, in the long run.

Thus, it is concluded that Ufone has a much better and more effective system to manage churn and retain its customers than Telenor does. Telenor was able to attract a number of customers soon after its introduction, but lack of vision and ineffective retention planning played havoc with the subscriber's level of satisfaction, and a number of customers gave up the service. This observation becomes all the more valid through the selected sample chosen for the specific study.

\section{LIMITATIONS}

A major limitation faced during the research work has been the fact that Telenor's management was reluctant to disclose information about churn handling due to the recent blasphemy episode, which was brought about by publication of undesired material in a Danish newspaper. Public sentiment was provoked due to which major European organisations were targeted for destruction of property. Another issue brought to light is the operational definition of churn, the time period of which is not uniform across the industry, making it difficult to ascertain its actual level.

\section{RECOMMENDATIONS}

The following recommendations have been put forward on the basis of this study:

Customer retention, must be a part of the planning phase along with customer acquisition, in all telecommunication organisations. It has been observed that organisations tend to focus upon churn management only when the customer base has deteriorated. There seems to be a lack of contingency planning in this particular aspect of the growing industry. The 
management of Telenor should specifically focus on customer retention and not just on acquisition phase. It should establish a separate retention/churn management department to deal with this emergent issue in Pakistan's telecommunication industry. Ufone and Telenor should also be prepared for the upcoming 'MNP' as this facility will result in greater churn rates. MNP is a system that enables a mobile phone subscriber to retain his/her number while changing the cellular service provider. The facility will act as a pressure on cellular service providers to improve the quality of their services in order to retain their customers.

\section{References and Notes}

1 Pakistan Telecommunication Authority, Annual Report 2005.

2 PTA Annual Report 2005.

3 Qian, Z., Jiang, W. and Tsui, K. -L. (2006) 'Churn detection via customer profile modeling', International Journal of Production Research, Vol. 44, No. 14, pp. 2913-2933.

4 Aydin, S. and Özer, G. (2006) 'How switching costs affect subscriber loyalty in the Turkish mobile phone market: An exploratory study', Journal of Targeting, Measurement and Analysis for Marketing, Vol. 14, No. 2, pp. 141-155.

5 Bairsto, A. (2001) 'Customer retention and churn management,' Chorleywood Consulting, ISBN-10 1903950252 ; ISBN-13 9781903950258.

6 Yankee group (2001) 'Churn management in the mobile market: A Brazilian case study’, Pub ID: YANL696399.

7 Lejeune, M. A. P. M. (2001) 'Measuring the impact of datamining on churn management', Internet Research: Electronic Networking Applications and Policy, Vol. 11, No. 5, pp. 375-387.
8 Heejin, L., Richard, W. and Jungkun, P. (2006) 'M-loyalty: Winning strategies for mobile carriers', Journal of Consumer Marketing, Vol. 23, No. 4, pp. 208-218.

9 Riivari, J. (2005) 'Mobile banking: A powerful new marketing and CRM tool for financial services companies all over Europe', Journal of Financial Services Marketing, Vol. 10, No. 1, pp. 11-20.

10 Ultsch, A. (2002) 'Emergent self-organising feature maps used for prediction and prevention of churn in mobile phone markets', Journal of Targeting, Measurement and Analysis for Marketing, Vol. 10, No. 4, pp. 314-324.

11 Alvarez, J. G., Raeside, R. and Beresford Jones, W. (2006) 'The importance of analysis and planning in customer relationship marketing:Verification of the need for customer intelligence and modelling', The Journal of Database Marketing \& Customer Strategy Management, Vol. 13, No. 3, pp. 222-230.

12 Caruana, A. (2004) 'The impact of switching costs on customer loyalty: A study among corporatecustomers of mobile telephony', Journal of Targeting, Measurement and Analysis for Marketing, Vol. 12, No. 3, pp. 256-268.

13 Evans, M. (2002) 'Prevention is better than cure: Redoubling the focus on customer retention', Journal of Financial Services Marketing, Vol. 7, No. 2, pp. 186-198.

14 Xevelonakis, E. (2005) 'Developing retention strategies based on customer profitability in telecommunications: An empirical study', The Journal of Database Marketing \& Customer Strategy Management, Vol. 12 No. 3, pp. 226-242.

15 Mattison, R. (2001) 'Telecom Churn Management: The Golden Opportunity', APDG Publishing.

16 Kaya, S. and Williams, B. (2005) 'Effective churn management for business', Journal of Corporate Real Estate, Vol. 7, No. 2, pp. 154-163.

$17 \mathrm{Lu}$, J. (2002) Predicting Customer churn in the telecommunications industry - An application of survival analysis modeling using SASA', Overland Park Sprint Communications Company, Kansas.

18 Cited on the official website of Telenor. 